\title{
STATE REGULATION OF THE DEVELOPMENT OF CORPORATE SOCIAL RESPONSIBILITY IN THE TRANSFORMATION TYPE COUNTRIES IN EASTERN EUROPE
}

\author{
Ivan Parubchak', Nadiia Radukh²
}

\begin{abstract}
The purpose of this research is to investigate the processes of formation of corporate social responsibility in countries of transformation type in Eastern Europe and to study the perspectives of development of socially responsible investing based on studying the world experience in the field of corporate responsibility and the practices of its realization by economic entities in the world. The theoretical and methodological basis of the research is the dialectical method of cognition of the processes of formation of corporate social responsibility in transformation societies, using the experience of the foreign community in similar processes and the possibility of applying individual practices in domestic business. The following scientific methods were used in the research: abstract-logical, in particular, its methods of generalization, analogy, analysis and synthesis, induction and deduction for the formulation of theoretical generalizations of research results, formulation of conclusions and suggestions. Main objects of the study are: theoretical bases of formation and realization of mechanisms of state regulation of corporate social responsibility and socially responsible investing in the world and opportunities to apply their experience in the countries of Eastern Europe; determining the current level of corporate social responsibility at enterprises and organizations and assessing the prospects for their development and influence on socio-economic processes. Practical implications. The stakeholder theory is considered, which reveals the essence of corporate social responsibility in the process of satisfying interests and requirements of various counterparties that may affect the ultimate financial results of the enterprise. It is determined that the main causes of state regulation of corporate social responsibility are a moral obligation, sustainability, and reputation. Corporate social responsibility is an effective tool for enterprise development, as well as for the development of the process of state regulation and constructive dialogue with different social categories that enhances the investment attractiveness of the enterprise and strengthens its reputation, promotes effective labour relations and enhances productivity, supports the marketing policy and trust of the target audience by forming a positive opinion about products, works or services of the enterprise. Modern strategies on the basis of which companies perform the formation of their investment portfolios are considered (sustainable investment strategy, norms-based screening and exclusion of holding from investment universe, integration of ESG factors in financial analysis, impact investments, engagement and voting on sustainability matters). The issue of the undeveloped practice of submitting social reports and difficult public access to them by stakeholders is considered. A model for analysing the prospects of corporate social responsibility development at enterprises is proposed; corporate social responsibility strategy provides for the fulfilment of economic, social, and environmental goals for the successful implementation of corporate social responsibility and socially responsible investment initiatives.
\end{abstract}

Key words: corporate social responsibility, investments, socially responsible investing, strategy, transformation, state regulation, countries of Eastern Europe.

JEL Classification: D30, H70, M14, O16

\footnotetext{
Corresponding author:

${ }^{1}$ Stepan Gzhytskyi National University of Veterinary Medicine and Biotechnologies Lviv, Ukraine.

E-mail: parubchak io@ukr.net

ORCID: https://orcid.org/0000-0002-7664-5062

${ }^{2}$ Stepan Gzhytskyi National University of Veterinary Medicine and Biotechnologies Lviv, Ukraine.

E-mail: nraduh@ukr.net

ORCID: https://orcid.org/0000-0001-7851-7964
} 


\section{Introduction}

Globalising processes taking place in today's transformational socio-economic conditionals create new challenges for businesses on their way to economic growth and enhancing competitiveness, expanding additional opportunities for integration with foreign partners and investors. When deciding how to invest financial resources for the best profit, potential investors consider a number of factors (risk, profitability, taxes, inflation, dividends, diversification), which complicate the decision-making process and require detailed planning and study of the situation. In the current condition, investors are choosing their object of investment, more times make the decision not only to invest in financial assets and financial stability of enterprises but also to evaluate their social benchmarks and participation in environmental protection, social justice, and corporate governance; in other words, achieving sustainable development indicators.

Problems of corporate social responsibility and socially responsible investing are widely researched in foreign scientific works and are gaining increasing interest and thorough study by domestic scientists. Theoretical underpinnings of corporate social responsibility have been reflected in the works $M$. Peteraf and J. Barney (2003), A. McWilliams and D. Siegel (2006), S. Kotsantonis, C. Pinney, and G. Serafeim (2016). Among Ukrainian scientists, new approaches to the formation and development of corporate social responsibility of enterprises that provide the implementation of programs of social investment are offered by O. Lazorenko and R. Kolyshko (2008), N. Orlova and A. Kharlamova (2014) explore conceptual foundations of corporate social responsibility, D. Bayura (2017) studies social investment as a higher level of corporate social responsibility.

The purpose of this research is to investigate the processes of formation of corporate social responsibility in countries of transformation type of Eastern Europe and to study the perspectives of development of socially responsible investing based on studying the world experience in the field of corporate responsibility and the practices of its realization by economic entities in the world. The theoretical and methodological basis of the research is the dialectical method of cognition of the processes of formation corporate social responsibility in transformation societies, using the experience of the foreign community in similar processes and the possibility of applying individual practices in domestic business. The following scientific methods were used in the research: abstract-logical, in particular, its methods of generalization, analogy, analysis and synthesis, induction and deduction for the formulation of theoretical generalizations of research results, formulation of conclusions and suggestions.
Main objects of the study are: theoretical bases of formation and realization of mechanisms of state regulation of corporate social responsibility and socially responsible investing in the world and opportunities to apply their experience in the countries of Eastern Europe; determining the current level of corporate social responsibility at enterprises and organizations and assessing the prospects for their development and influence on socio-economic processes.

\section{Essence and main determinants f corporate social responsibility at enterprises in countries of transformation type}

Foreign scientists define corporate social responsibility as a situation where a firm goes beyond its compliance and takes actions that promote a certain social product that goes beyond the interests of the firm and the requirements of the law (McWilliams et al, 2006). More broadly, corporate social responsibility involves social characteristics into products and manufacturing processes (the use of clean technologies), making effective methods of management human resource (promoting empowerment of employees, improving their skills, additional training), achieving higher levels of eco-efficiency through recycling and reducing the pollution of the environment. In E. Freeman's view (1984) and his stakeholder theory, managers must satisfy interests and requirements of the various counterparties (workers, customers, suppliers, local communities), which may affect the ultimate financial result of the enterprise (Ernst and Young, 2011). According to this theory, it is not enough to focus solely on needs of shareholders or business owners but it is necessary to carry out socially responsible areas of work that are relevant for non-financially stakeholders because they have an indirect influence on the enterprise, its financial result and reputation and, accordingly, the market value of the enterprise.

In the world practice, the main focus is on American and European models of corporate social responsibility. The American model of socially responsible behaviour is simply put into practice and its results are public. In an investor's view, the participation of the company in socially responsible activity characterizes it as socially stable; therefore, it is more attractive for external investors. This model has received positive approval from employees of companies, public and non-governmental organization because it meets their social needs. The basis of the European model of social responsibility is a state as it has an interest in a stable society, and since society is represented by workers, so corporate social responsibility takes on forms of responsibility to employees (Lazorenko, Kolyshko, 2008).

Corporate social responsibility is not a mandatory initiative but its implementation is important for all economic actors since, in the course of their activity, they 
interact with internal and external stakeholder groups (employees, clients, communities, public organizations, government, and international structures) (Orlova, Kharlamova, 2014).

Corporate social responsibility is an effective tool for the self-development of enterprise, as well as for the development of system state regulation and constructive dialogue with various sectors of society. It enhances investment attractiveness of the enterprise and strengthens its reputation, promotes effective labour relations and increases productivity, supports the marketing policy and trust of the target audience, forming a positive opinion about the goods, works or services of the enterprise. Scientists are expanding their research not only to find a definition of corporate social responsibility but also to identify activities of socially responsible enterprises and organizations in order to assess the strategic role of corporate social responsibility in their sustainable development.

Socially responsible investment does not differ in nature from other types of investment; differences can be traced in an investor's ability to realize them. If a business is more efficient than other entities in socially responsible investing, it can give it a competitive advantage (Peteraf, Barney, 2003). If resources that the firm uses to gain this competitive advantage are pathdependent, socially complex or causally ambiguous, it can be a source of sustainable competitive advantage. A firm with a strong competitive advantage in financing socially responsible activities will attract a greater share of socially conscious investors to the economy than other entities that make a similar investment. A firm with a strong competitive advantage in financing socially responsible activities can have a relatively high market value, even when the supply of socially responsible investment opportunities exceeds the demand for these opportunities. This is because, among all counterparties that make a socially responsible investment, a competitive advantage company will be able to attract investors differently (Mackey et al, 2007). Sustainable development companies in Eastern Europe find a competitive advantage in the commodity, labour, and capital markets and their investment portfolios, which include sustainable development indicators, provide average returns for their investors that outperform conventional investment portfolios and illustrating less risk (Kotsantonis et al., 2016).

\section{The relationship between corporate social responsibility and socially responsible investing}

Socially responsible investing (SRI) is a long-term investment approach that integrates sustainable development factors (environment, society, and state) into the process of research, analysis and choice an enterprise's investment portfolio, combining fundamental analysis and engagement of ESG factors to better capture long-term returns for investors and benefit society by influencing company behaviour (Eurosif, 2018).

SRI is a process of choosing investment based on social benefits and financial benefits and is focused on exploring aspects such as: clean environment (investors prefer non-polluting companies); social justice (investors do not work in countries that violate human rights and work with business that provide fair wages and decent working conditions for their employees); promoting peace (investors avoid arms-producing or profitable conflict in foreign countries); health and morale promotion (many socially responsible investors refuse to invest in businesses that sell tobacco, alcohol, or genetically modified organisms, as well as in gambling or other immoral areas).

Social investment is a higher form of management or a level of corporate social responsibility, which can become an effective tool for the development of companies in Eastern Europe and an instrument of state regulation of social processes (Bauyra, 2011).

Global trends of increasing socially responsible investing are confirmed by the fact that today the number of strategies on the basis of which companies carry out their investment portfolios has increased. In particular, it is sustainable investment strategy, norms-based screening and exclusion of holding from investment universe, integration of ESG factors in financial analysis, impact investments, engagement and voting on sustainability matters (Eurosif, 2018).

In the process of achieving social goals, the most commonly used investors are four strategies:

- exclusion of holding from investment universe or socially responsible selection, which involves refusing to invest in companies that do not meet the established social standards, while extracting all assets from specific companies because of how or where they do business;

- positive investment: choosing companies to include in your portfolio precisely because you approve of their behaviour;

- community investment. This is a special subcategory of positive investment that focuses specifically on investment of non-governmental organizations, especially in low-income areas. It provides loans to individuals and organizations with solvency problems. These loans can use to finance small businesses, housing, and education;

- shareholder action. Socially responsible investors not only use their values to choose companies for their portfolios - they also try to influence the behaviour of companies in which they are shareholders.

A key agent of influence on a social responsibility strategy is external pressure on firms, which makes them think about corporate social responsibility in accordance with social priorities rather than individual motives. The main common reasons for companies 
to carry out corporate social responsibility are: moral obligation (a duty to be good citizens and to "do right"), sustainability (long-term ability to work requires environmental and community governance), and reputation (CSR initiatives can enhance an organization's reputation, leading to improve business conditions).

\section{The experience of Eastern European countries and the perspective of developing corporate social responsibility in transformational conditions}

Corporate social responsibility can be defined as one that aims to provide business entities with obligations to the state and society in terms of paying taxes, health and safety at work, rights of workers and consumers, environmental standards and industry standards. It enhances a positive impact on society and value creation through innovation, investment and partnership, providing the creation of jobs, social and economic development, resolution of conflict. The need for the development of corporate social responsibility in the countries of transformation type of Eastern Europe is due, in particular, to a number of factors:

- low level of business activity and financial stability of a significant proportion of enterprises. The activities of economically weak entities are oriented towards survival, and the state often takes a firm stance on enterprises, so a constant shortage of funds does not contribute to the realization of social responsibility at the national level;

- low legal awareness and desire to circumvent the law rather than obey it, which is partly explained by the quality of the laws, their instability and selective application;

- low level of public awareness of the importance of entrepreneurship - due to the relatively short-lived modern history of business and even shorter practice of realizing its own social responsibility, since the correct understanding of business efforts in this direction is hardly formed;

- terminological (regulatory) uncertainty - lack of clear tasks and mechanisms of state regulation of social responsibility;

- inaccessibility of information to the public about the activity of enterprises - for the most enterprises detailed information about its activity is data for internal use only. Information about mission, code of ethics, proclaimed values are provided by large enterprises;

- disparities in the implementation of social responsibility policy by Ukrainian enterprises. Corporate social responsibility of companies in Eastern European countries is focused on labour relations and measures to protect the health and safety of consumers, measures to protect natural resources and the environment, community engagement is not provided by enterprises in sufficient quantities. Measures for the protection of natural resources and environmental protection, interaction with the community are not provided by enterprises in sufficient volumes;

- imbalance in stakeholder interests: interests of consumers and public authorities are the most often take into account, and the least often non-governmental organizations.

The main feature in the development of social responsibility of enterprises of transformation countries is that at the regional and state levels, the social contribution is reduced to the forced participation of business in the implementation of various social and cultural programs.

Other features of the Eastern European corporate social responsibility model include:

- lack of ideology of socially responsible entrepreneurship and low level of civic awareness;

- absence of clear mechanisms of formation and implementation of the state social policy at the country, regional, and enterprise level;

- high variability of forms of social activity formed at individual enterprises of countries of transformation type;

- high differentiation of social corporate benefits, which are aimed only at the top executives.

In the current conditions, there are problems of implementation and spread of socially responsible investment by companies in Eastern Europe, which are caused by a few factors:

- lack of performance targets planned for executives and managers associated with SRI implementation;

- lack of methods of measuring economic effect of socially responsible investments that affect the business reputation of enterprise, the professional qualities of employees, and the volumes of sales;

- difficulties in measuring the social effect of socially responsible investing, when it is almost impossible to evaluate the results of charitable assistance or volunteering, although some foreign companies use the amount of time spent on charity or the amount of money received from such work as a generic indicator; - undeveloped social reporting practices and difficult public access to stakeholder reports. Only large enterprises engaged in foreign economic activity present such reports, SMEs either do not make a socially responsible investment or are under no obligation to submit such reports;

- the vast majority of enterprises study the behaviour of consumers of their products while forgetting about their environmental impact, consumer protection, business ethics;

- unwillingness to inform consumers and stakeholders about their environmental impact by affixing appropriate marking on the packaging.

Business leaders need to understand socially responsible investing is a strategic step in government 
regulation and ensuring corporate social responsibility since its results are gradually accumulating and creating a good business reputation and awareness among a large number of stakeholders, opportunities for attracting foreign investment and foreign cooperation, which indirectly affect the final financial result of the activity.

Entrepreneurs should analyse own social responsibility opportunities and use the same criteria as when choosing a core business. They should bear in mind that corporate social responsibility can be a powerful source of innovation and competitive advantage. In order to achieve this goal, it is necessary to consider the relationship between business and society, aimed at corporate growth and social well-being. This will help the company identify the social consequences of their actions and opportunities to benefit the community and themselves by enhancing the competitive context in which they operate.

\section{Proposals for further development of corporate social responsibility for business in countries of transformation type of Eastern Europe}

State regulation of the development of corporate social responsibility should be implemented by the following measures:

- formation of normative and legal conditions for the development of social responsibility: to form a permanent body whose competence would be to analyse the current state of corporate social responsibility and regional structures for the development of corporate social responsibility of enterprises and organizations;
- create a system of benefit and preferences for organizations that implement social responsibility policies and implement the socially important program; encourage the dissemination of social reporting by businesses and organizations;

- develop the capabilities and competencies of enterprises and organizations to support them in the implementation of social responsibility: facilitate the exchange of experience and the improvement of corporate governance and the dissemination of corporate social responsibility strategies at enterprises; - increase the availability of corporate social responsibility information among various stakeholder groups: to conduct information events, to publicize information regarding companies that violate the principles of consumer protection and the principles of corporate social responsibility; organise conferences for the implementation and effectiveness of corporate social responsibility with the support of state and local authorities, local communities. In order to develop corporate social responsibility, it is necessary to formulate a strategy of corporate social responsibility for the enterprise, and for this purpose, it is important to carry out a comprehensive analysis of enterprise activity (financial-economic, socioeconomic, and economic-environmental types of analysis) - Figure 1 .

Strategically planned work in the area of corporate social responsibility and investment can improve the efficiency of an enterprise's activity more effective than conducting a certain type of investment based

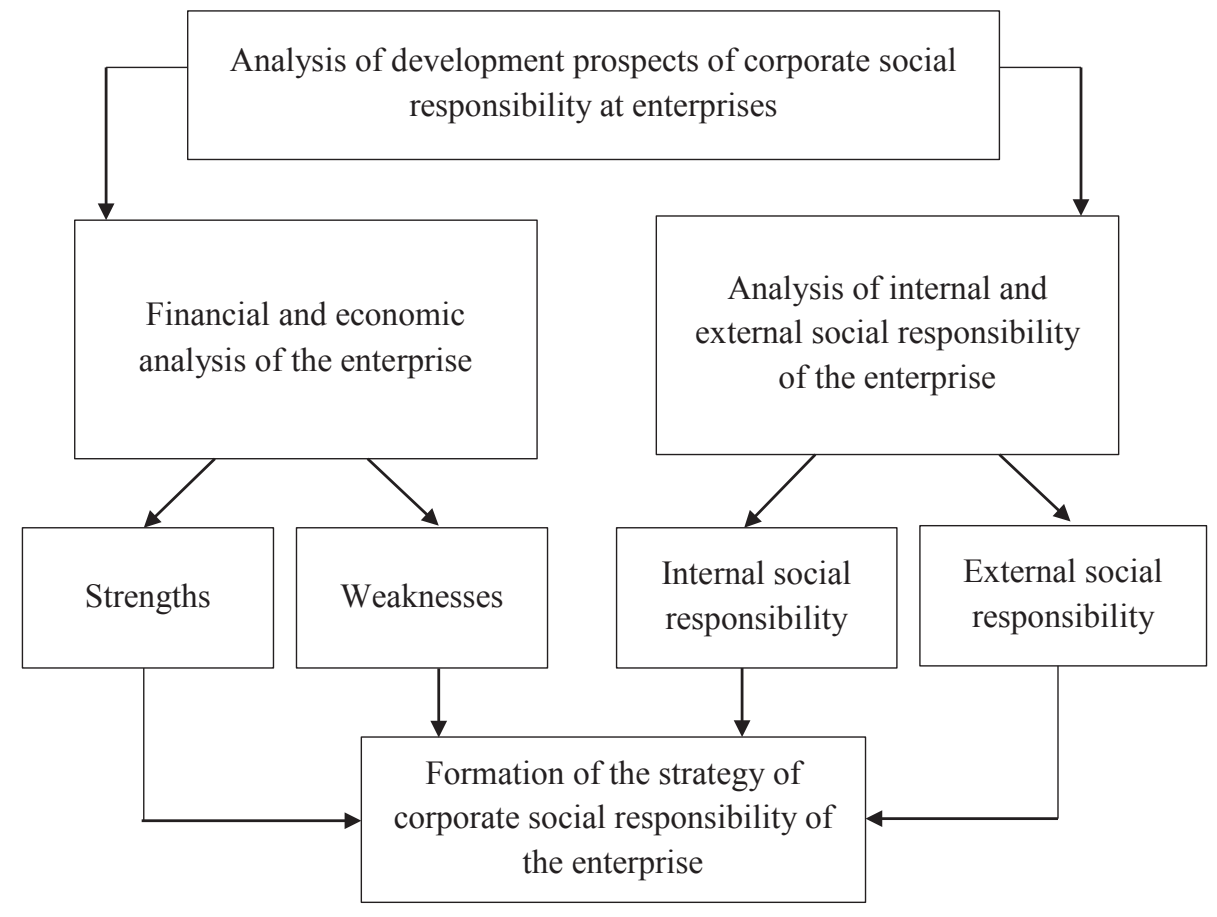

Figure 1. The model for analysing the perspectives of development of corporate social responsibility at enterprises in countries of transformation type of Eastern Europe 
on altruistic motivations. There is an ideal level of investment in CSR for each organization depends on its size, level of diversification, research and development, advertisement, sales, consumer incomes, conditions of the labour market, and an industry lifecycle. It can be determined by cost-benefit analysis (McWilliams, Siegel, 2001).

In addition, openness and transparency in communications is an important indicator in CSR of business, in evaluating business operations, formulating goals and plans for employees. Communication can have both a positive and negative impact on the CSR evaluation of a company. For first and foremost it depends on how professionally this process takes place at the company and beyond it. Stakeholders look to companies for leadership behaviour, not just risk management in global issues such as climate change, human rights, and reduction of poverty (Lazorenko, Kolyshko, 2008).

Thus, for the successful implementation of corporate social responsibility and socially responsible investing initiatives, a corporate social responsibility strategy is needed that will meet economic, social, and environmental goals - Figure 2.

In addition, for transformational societies, along with social responsibility, the priorities remain the areas of increasing the level of innovative development and competitiveness, corporate management, cooperation

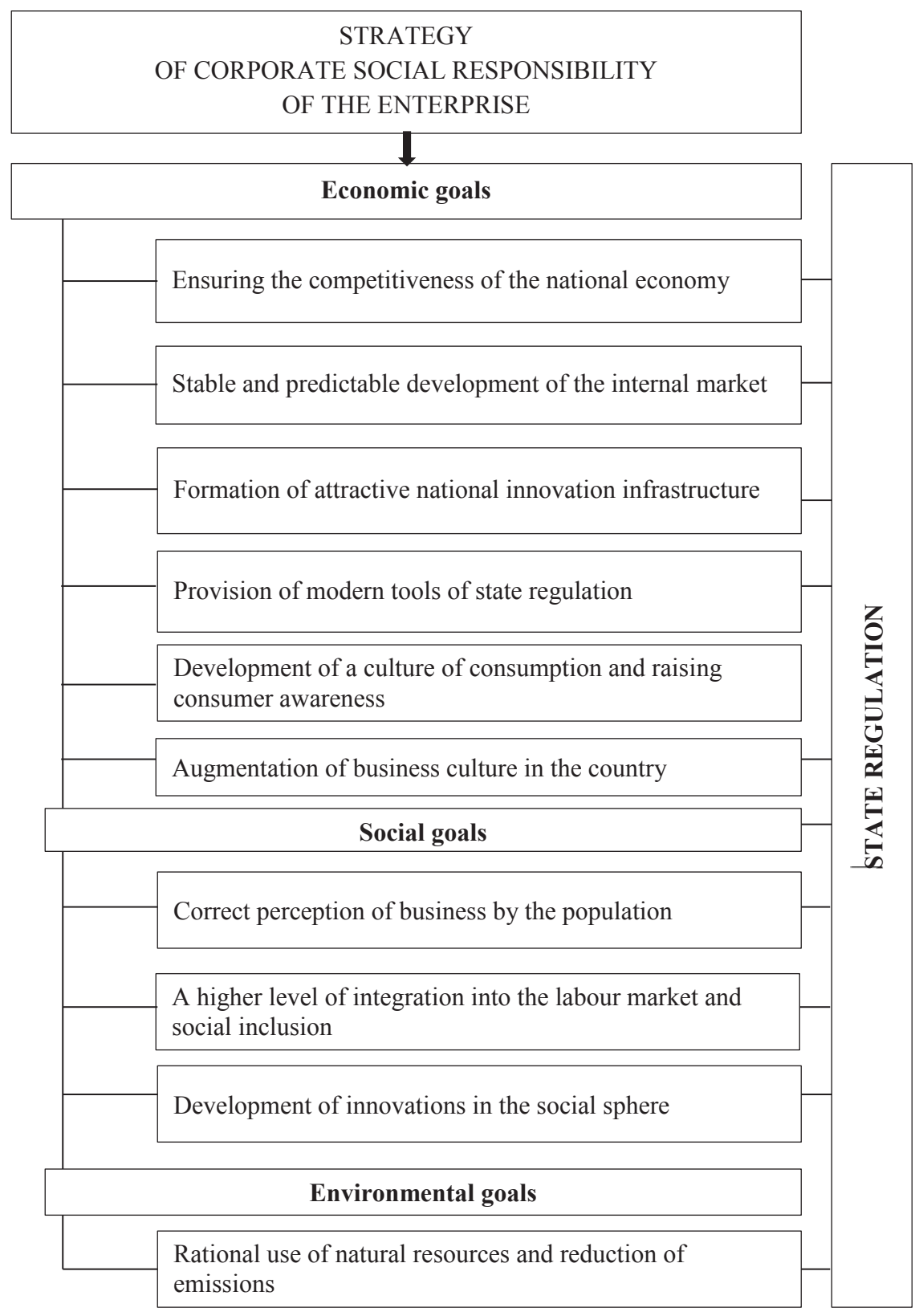

Figure 2. State regulation of the strategy of development of corporate social responsibility in the countries of transformation type 
with groups of influence, development of human resources; population well-being, entrepreneurship and initiative; preservation and reproduction of the environment; integration into the international community.

\section{Conclusions}

The basic theoretical aspects of corporate social responsibility formation and socially responsible investing in the world and the possibility of applying their practices in the countries of Eastern Europe are investigated; the level of corporate social responsibility at enterprises of the transformation type countries is analysed, and the model is suggested for analysing perspectives of development of corporate social responsibility at enterprises in countries of transformation type of Eastern Europe. Effective measures of state regulation of CSR development can be the formation of a comprehensive system of legislative and regulatory support of social responsibility, granting tax and investment privileges and preferences, encouraging the involvement of business entities in international cooperation. In the countries of Eastern Europe, there should be special responsible state units, which regulate the work in different directions of CSR, based on individual instruments depending on priorities of the socio-economic status of the country and the priority of its economic, environmental, and social development plans.

Further research may be aimed at developing proposals on improving mechanisms of state regulation of corporate social responsibility formation and socially responsible investing as a tool of corporate social responsibility in individual transformational countries in Eastern Europe.

\section{References:}

Bayura, D. O. (2011). Social investing as the highest level of corporate social responsibility. Theoretical and applied issues of economics. Collection of scientific works, 24, 212-219. Retrieved from: http://library.univ.kiev.ua/ukr/host/ viking/db/ftp/univ/ttppe/ttppe_2011_24.pdf\#page $=212$

Bayura, D. O. (2017). Developing corporate social responsibility in stakeholder support organizations. Economic Journal of Lesya Ukrainka Eastern European National University, 4(12), 39-44.

Ernst \& Young, "Climate change and sustainability: How sustainability has expanded the CFO's role," Ernst \& Young, 2011. Retrieved from: www.ey.com/US/en/Services/Specialty-Services/Climate-Change-and-SustainabilityServices/How- sustainability-hasexpanded-the-CFOs-role

Eurosif 2018 SRI Study. Retrieved from: http://www.eurosif.org/eurosif-2018-sri-study-launch-event/

Kotsantonis, S., Pinney C., \& Serafeim, G. (2016). ESG integration in investment management: myths and realities. Retrieved from: https://onlinelibrary.wiley.com/doi/abs/10.1111/jacf.12169

Lazorenko, O., Kolyshko, R., et al. (2008). CSR Handbook. Corporate Social Security Information. Energy Publishing House.

Mackey, A., Mackey, T., \& Barney, J. (2007). Corporate social responsibility and firm performance: Investor preferences and corporate strategies. Academy of Management Review, 32(3), 817-835.

McWilliams, A., \& Siegel, D. (2001). Corporate social responsibility: A theory of the firm perspective. Academy of Management Review, 26(1), 117-127.

McWilliams, A., Siegel, D., \& Wright, P. (2006). Corporate social responsibility: Strategic implications. Journal of Management Studies, 43(1), 1-18.

Orlova, N. S., \& Kharlamova, A. O. (2014). Conceptual principles of corporate social responsibility in Ukraine. Monograph. Donetsk.

Peteraf, M., \& Barney, J. (2003). Unraveling the resource-based tangle. Managerial and Decision Economics, 24, 309-323. 